Original Research Paper

\title{
Keberkesanan Aplikasi Mudah Alih 'Algoritma bersama Algo' bagi Pembelajaran Topik Algoritma dalam Subjek Asas Sains Komputer
}

\author{
Anis Syuhada Shaharom¹, Mohd Hishamuddin Abdul Rahman² \\ ${ }^{1}$ Program of ISMP Information Technology, Department of Computing. Faculty of Art, \\ Computing \& Creative Industry. Universiti Pendidikan Sultan Idris. Tanjong Malim, \\ Malaysia. \\ ${ }^{2}$ Department of Computing. Faculty of Art, Computing \& Creative Industry. Universiti \\ Pendidikan Sultan Idris. Tanjong Malim, Malaysia.
}

Article History
Received:
10.08 .2021
Revised:
20.08 .2021
Accepted:
27.08 .2021
*Corresponding Author:
Mohd Hishamuddin Abdul
Rahman
Email:
mhishamuddin@fskik.upsi.edu.my

This is an open access article, licensed under: $\mathrm{CC}-\mathrm{BY}-\mathrm{SA}$
Abstrak: Kajian ini bertujuan untuk membangunkan sebuah aplikasi mudah alih, Algoritma Bersama Algo untuk pelajar tingkatan 1 yang mengambil subjek Asas Sains Komputer bagi topik Algoritma. Pembangunan aplikasi ini berasaskan kepada permasalahan yang berlaku dalam kalangan guru mahupun pelajar yang sukar untuk mencari bahan rujukan. Pembangunan aplikasi ini dapat membantu para guru dan pelajar dengan menerapkan elemen-elemen multimedia dan teknologi maklumat. Seterusnya, kajian ini juga mengkaji persepsi pelajar dan guru terhadap penggunaan aplikasi dalam pembelajaran bab Algoritma. Metodologi kajian yang digunakan sebagai panduan dalam pembangunan aplikasi ini adalah ADDIE. Data kajian dikumpul dengan menggunakan soal selidik yang diedarkan kepada guru dan pelajar melalui Google Form. Hasil dapatan kajian memperlihatkan majoriti pelajar dapat menggunakan aplikasi dengan baik dan menarik minat pelajar untuk belajar. Cadangan pada masa akan datang adalah dalam menghasilkan sesuatu produk pembangun perlu kreatif dalam menerapkan elemen multimedia dalam menarik minat pengguna. Kesimpulan daripada kajian menunjukkan pembelajaran yang menarik mampu dijalankan walaupun diluar bilik darjah dengan menggunakan aplikasi mudah alih yang disediakan.

Kata Kunci: Alatan Pembelajaran, Algoritma, Aplikasi Mudah Alih.

Usefulness of the 'Algoritma bersama Algo' for Learning Algorithm Topic in Asas Sains Komputer Subjects

Abstract: This study aim to develop a mobile application, "Algoritma bersama Algo" for Form 1's student taking "Asas Sains Komputer" in Algorithm topic. This application development based on problem that occurred within both teacher and student that having dificulity in searching reference materials. This application can help both teacher and student to applied multimedia and information technology elements. Next, this study also examines the perceptions of students and teachers to use this application in learning about algorithm. Methodology used as guide in development of this application is ADDIE model. Data collected using questionnaires which distributed to students through Google Forms. The result showed that majority students can use application properly and it attract students to learn. Suggestion for the future is to produce a creative product as developer needs to implement multimedia elements to interest users. As conclusion, the study showed interesting learning can be carried out even outside the classroom using mobile applications that were develop.

Keywords: Algorithm, Learning Tool, Mobile Application. 


\section{Pendahuluan}

Dalam era ledakan maklumat ini, bidang teknologi merupakan satu bidang yang semakin mendapat tempat dan menjadi suatu keutamaan dengan peredaran masa yang kian berkembang pesat. Teknologi adalah sebuah aplikasi pengetahuan dalam bidang sains yang mereka cipta pelbagai alat canggih yang mampu meningkatkan lagi keupayaan manusia. Seperti yang kita sedia maklum, hampir setiap lapisan masyarakat menggunakan teknologi yang ada dan dengan teknologi jugalah menyebabkan kita mampu menguasai dan mengawal hampir setiap perkara di hujung jari sahaja. Hal ini kerana terdapat pelbagai inovasi dan penciptaan baharu yang telah dihasilkan selaras dengan perkembangannya serta kemajuan yang ada pada masa kini.

Perkembangan teknologi telah menyumbang dalam meningkatkan pengurusan dan pentadbiran negara ke arah yang lebih sistematik dan teratur [1]. Kewujudan teknologi telah memudahkan segala urusan tidak kira apa jua bidang seperti pentadbiran, pengurusan, penyiaran dan media, telekomunikasi, perhubungan dan segala bidang yang ada. Permodenan sesebuah negara dan masyarakat seringkali dikaitkan dengan pengaplikasian teknologi moden dalam pelbagai bidang khasnya dalam bidang pendidikan. Teknologi sentiasa membawa perubahan yang paling besar di sesebuah negara. Perkembangan pesat dalam bidang teknologi terutama Teknologi Maklumat dan Komunikasi (TMK) membawa banyak perubahan terhadap kaedah pengajaran dan pembelajaran (PdPc) dalam kalangan guru-guru.

Menurut Kaware [2], TMK merupakan suatu kombinasi alat dan sumber teknologi yang digunakan untuk manipulasi serta menghubung kait antara maklumat. Peralatan teknologi yang dimaksudkan adalah seperti peralatan elektronik dan digital. Misalnya penggunaan teknologi seperti komputer, internet, dan teknologi multimedia yang lain. Menurut Sukendar et al. [3], teknologi maklumat dalam konteks pandidikan ialah peralatan teknologi komunikasi atau sistem rangkaian elektronik dan komputer yang boleh digunakan untuk mengumpul, menyimpan, memproses, menyalurkan dan menyampaikan maklumat secara pantas dan tepat. Contoh teknologi maklumat masa kini yang dapat membantu proses PdPc ialah internet dan multimedia.

Proses pembaharuan dalam bidang pendidikan jelas dilihat dari aspek perkembangan dan pengintegrasian komputer dan pengaplikasian. Ianya adalah selaras dengan perkembangan TMK yang telah menjurus kepada suatu zaman baharu yang dikenali sebagai "Arena Ledakan Maklumat" yang dipengaruhi oleh alatan elektronik terutama dalam bidang pendidikan. Kementerian Pelajaran Malaysia (KPM) telah berusaha menggabungkan teknologi maklumat dan komunikasi sebagai salah satu usaha bagi melaksanakan aktiviti PdPc di sekolah rendah hingga ke peringkat pengajian tinggi.

Penggunaan teknologi maklumat dan komunikasi menjadi semakin penting dalam bidang pendidikan kerana kemampuan menyediakan persekitaran pembelajaran dan pengajaran yang proaktif [4]. Menurut Norazrena \& Khairul [5], Ibrahim et al. [6], menyatakan bahawa penerapan TMK adalah suatu proses teknologi yang disesuaikan dengan kondisi pembelajaran dan pengajaran tidak kira dalam kelas atau sebaliknya. Disamping itu, penerapan TMK dalam pendidikan mampu membangunkan kompetensi pelajar mengikut keperluan global dengan pembentukan kemahiran serta penambahan ilmu pengetahuan. Walaubagaimanapun, integrasi TMK perlulah bersesuaian dengan kondisi dan suasana pembelajaran di Malaysia. Perisian yang sesuai dengan latar belakang pelajar perlu diambil kira bagi memastikan integrasi TMK yang efektif. Hal ini dapat dilihat bahawa penerapan TMK dapat menambah baik serta meningkatkan kualiti pembelajaran pelajar dan pengajaran guru.

PdPc yang menggunakan TMK terbukti dapat membantu meningkatkan minat dan perhatian pelajar, membantu perkembangan literasi, dan kemahiran pemikiran tahap tinggi. Oleh hal demikian, perubahan pedagogi menggunakan TMK sememangnya penting dalam memastikan proses pengajaran dan pembelajaran menjadi lebih menarik dan berkesan [7]. Oleh itu, penggunaan TMK dalam pendidikan mestilah melihat kepada proses mengaplikasi peralatan dengan menggunakan prinsip, kaedah, dan teknik yang sesuai dalam pengajaran dan pembelajaran [8].

Sedasarwasa ini, pendidikan di -Malaysia semakin berubah secara dinamis kini mengalami banyak perubahan dan pembaharuan ke arah abad ke-21. Hal ini kerana, kerajaan bermatlamat untuk menjadikan Malaysia sebagai pusat kecemerlangan pendidikan (center for academic excellence) di rantau Asia yang memerlukan negara ini meningkatkan kecemerlangan imej serta kualiti pendidikan bertaraf dunia atau memperolehi status "World Class Education". Menurut Esa \& Padil [9], pendidikan bertaraf dunia perlu menunjukkan perkembangan dan kemajuan pesat serta dinamis dari segi kualiti, kuantiti, standard kecemerlangan dan kreadibiliti yang diakui dan diterima di peringkat antarabangsa.

Sebagai sebuah negara yang berkembang pesat dalam pelbagai aspek pembangunan, sektor pendidikan perlu berkembang dan mengalami anjakan paradigma yang dapat merintiskan alaf baru 
dalam segala aspek. Selaras dengan itu, Kementerian

Pendidikan Malaysia telah membuat beberapa perubahan iaitu Kurikulum Standard Sekolah Menengah (KSSM) dilaksanakan mulai tahun 2017 secara berperingkat bermula dengan Tingkatan 1 yang akan mengantikan Kurikulum Bersepadu Sekolah Menengah (KBSM). Melalui KSSM, salah satu mata pelajaran yang baharu diperkenalkan ialah Asas Sain Komputer (ASK) yang diajar kepada pelajar pada peringkat rendah. ASK merupakan kesinambungan mata pelajaran Teknologi Maklumat dan Komunikasi (TMK) yang telah diperkenalkan kepada pelajar di sekolah rendah serta mengantikan program Information and Communication Technology Literacy (ICT) di sekolah menengah pada tahun 2007.

Selaras dengan hasrat untuk melahirkan pelajar yang mempunyai kemahiran berfikir seperti yang terkandung dalam Pelan Pembangunan Pendidikan Malaysia (PPPM), mata pelajaran ASK diperkenalkan adalah bertujuan untuk pelajar mengetahui tentang prinsip-prinsip asas dan konsep pembinaan teknologi digital supaya menjadi individu yang mempunyai pemikiran komputasional serta memahami bahawa teknologi digital pada hari ini mampu menyelesaikan masalah masa hadapan.

KSSM ASK bermatlamat untuk menyediakan pelajar yang berpentahuan dan meliki kemahiran pemikiran komputasional. Kemahiran ini dapat melengkapkan pelajar dengan pengetahuan dan kemahiran asas sains komputer yang merangkumi kemahiran pengaturcaraan dan algoritma. Melalui kemahiran ini secara tidak langsung dapat melahirkan pelajar yang kreatif, inovatif, dinamik dan beretika dalam mengamalkan budaya TMK.

Salah satu topik penting dalam mata pelajaran ASK ialah Algoritma, yang diperkenalkan bagi membantu pelajar dalam mengaplikasi pemikiran komputasional yang telah dipelajari sebelum memasuki topik Algoritma. Topik ini telah merangkumi kaedah dalam membina Algoritma melalui pseudokod dan carta alir. Pelajar dapat menerangkan penggunaan Algoritma dalam menyelesaikan masalah. Dalam pada itu, pelajar juga dapat menggunakan Algoritma dalam menyelesaikan masalah dengan mengaitkan dengan kehidupan seharian. Algoritma ini sangat penting untuk dipelajari oleh pelajar kerana ia merupakan salah satu langkah awal yang perlu dilaksanakan sebelum suatu fail pengaturcaraan komputer ditulis.

Selaras dengan pembelajaran abad ke-21 ini dimana penggunaan teknologi maklumat dalam pendidikan sangat digalakkan. Hal ini kerana, dengan penggunaan teknologi pelajar akan lebih memahami dimana konsep Algoritma ini digunakan. Secara amnya, kemunculan teknologi multimedia dalam pendidikan mendapat sambutan yang sangat menggalakkan dari setiap lapisan masyarakat. Menurut Tien L.T., \& Kamisah Osman [10] menyatakan bahawa pelajar yang menggunakan modul multimedia bersama agen pedagogi memperoleh keputusan yang lebih baik. Kewujudan eleman multimedia ini mampu mengembangkan lagi potensi pelajar secara optimal dan menjadi proses pembelajaran dapat dilaksanakan dimana sahaja dan pada bila-bila masa sahaja yang dimahukan. Oleh itu, penggunaan teknologi multimedia ini perlu digunakan dengan semaksimum yang mungkin. Hal ini kerana elemen multimedia dapat menyentuh seluruh media pendidikan hanya dalam satu perisian.

Tambahan lagi, kepelbagaian aplikasi yang ada pada masa kini telah diinovasikan dalam kaedah pengajaran dan pembelajaran. Menurut Mutalib [11], setiap sekolah disarankan untuk mengintegrasikan penggunaan aplikasi yang bersesuaian selaras dengan kurikulum khususnya dalam penggunaan mata pelajaran ASK di sekolah menengah. Pembelajaran ASK perlu dijadikan sebagai mata pelajaran yang memberikan pengalaman yang menyeronokkan serta mencabar bagi semua pelajar. Oleh hal yang demikian, pelbagai kaedah perlu diketengahkan agar pembelajaran pelajar lebih bermakna dan berkesan. Salah satu kaedah yang boleh digunakan adalah pembelajaran secara elektronik. Hal ini bertujuan untuk membantu pelajar dalam memperoleh maklumat serta meningkatkan pemahaman dalam sesebuah topik tanpa memperuntukan masa dan boleh dilaksankan diluar waktu persekolah. Pembelajaran yang boleh dilaksnakan pada bila-bila masa ini adalah melalui pembinaan aplikasi pembelajaran yang dipaparkan di skrin telefon pintar yang dimiliki oleh pelajar atau ibu bapa mereka.

Perkembangan teknologi dari segi telefon pintar sudah tidak asing lagi, malah ia menjadi satu fenomena yang kian disebut dan mendapat tempat utama dalam segenap masyarakat. Penggunaan aplikasi mudah alih juga semakin menyeluruh dalam bidang pendidikan. Pembelajaran menggunakan peranti telefon pintar merupakan satu perkembangan revolusi bagi media mudah alih [12] [13].

Kajian yang dilaksanakan ini adalah mengenai pembangunan aplikasi mudah alih yang menggunakan sistem operasi Android sebagai medium pembelajaran ASK Tingkatan 1. Aplikasi mudah alih yang dibangunkan ialah aplikasi Algoritma Bersama Algo yang berkonsepkan MPembelajaran. Melalui pembangunan aplikasi Algoritma 
Bersama Algo pelajar dan guru dapat mencari pelbagai maklumat dan rujukan dengan mudah. Maklumat yang dicari semuanya berada di hujung jari tanpa perlu bersusah payah untuk membuat rujukan.

Pembangunan aplikasi Algoritma Bersama Algo adalah berasaskan elemen-elemen multimedia seperti animasi, grafik, audio, video dan teks adalah untuk mempelbagaikan kaedah pengajaran bagi mata pelajaran ASK. Penggunaan elemen ini sangat penting dalam menarik minat pelajar. Hal ini kerana, pelajar pada masa kini lebih terarah kepada pembelajaran moden dan mereka akan mula meminati sesuatu aplikasi bedasarkan elemen-elemen yang diterapkan kedalam mana-mana aplikasi sekalipun. Pembangunan ini juga adalah bertujuan untuk menambah bahan rujukan bagi mata pelajaran ASK yang baharu diperkenalkan oleh KPM. Bedasarkan pemerhatian, bahan rujukan di kedai-kedai buku bagi mata pelajaran ini sememangnya sedikit berbanding dengan mata pelajaran yang lain. Hal ini menyukarkan para guru dan pelajar untuk membuat rujukan bagi mata pelajaran ini. Bahan rujukan bagi mata pelajaran ini tidak banyak dikeluarkan di kedai-kedai buku, malah para guru perlu menempah bahan rujukan daripada penerbit yang sememangnya memiliki ilmu mengenai mata pelajaran ini.

Selain itu, pembangunan aplikasi ini adalah bagi menyelesaikan permasalahan dalam membantu guru menginovasikan pendidikan daripada pendekatan secara tradisional kepada penggunaan teknologi. Menurut Martin \& Ertzberger [14], pencapaian yang rendah atau kurang dalam kalangan pelajar sering dikaitkan dengan kelemahan dalam akademik untuk menguasai sesuatu kemahiran akademik dan dikenali sebagai slow leaners. Faktor kegagalan guru dalam penggunaan pendekatan pengajaran dan pembelajaran yang sesuai menyebabkan pelajar berasa bosan, mengantuk dan berasa jemu. Suasana yang diamalkan didalam kelas adalah berpusatkan guru yang menyebabkan pelajar cepat berasa bosan. Pendekatan PdPc dalam sesuatu mata pelajaran perlu mencabar kebolehan dan serta mempertingkatkan pemikiran pelajar. Ini merupakan kriteria yang amat penting yang perlu dititikberatkan bagi menjadikan PdPc lebih bersifat inovatif dan kreatif bagi mengembangkan minda kritis seseorang pelajar.

\section{Kajian Literatur}

Dalam kajian literatur terkandung maklumat mengenai tinjauan literatur yang bersesuaian, kajian ke atas produk lampau, kelebihan dan kekuatan produk yang digunakan berbanding produk semasa.

\subsection{Aplikasi Mudah Alih dalam Pendidikan}

Aplikasi mudah alih atau Mobile Apps merupakan sebuah program yang dimuatkan ke dalam alat mudah alih dan boleh digunakan dimana-mana dan bila-bila masa sahaja (Md. Rashedul, Md. Rofiqul \& Tahidul Arafhin, 2010). Pelbagai aplikasi direka khas dalam telefon bimbit untuk memudahkan pengguna berkomunikasi, mencari maklumat, melayari internet, menyesun fail, membuat dokumen ringkas dan program hiburan. Pada era ini, teknologi mudah alih menjadi suatu kegilaan pelajar, mahasiswa mahupun golongan belia masa kini. Hal ini kerana pelbagai aplikasi sosial seperti Telegram, Whats App, Twitter, Wechat, Facebook, Instagram dan lain-lain seperti suatu yang wajib dimiliki oleh mereka.

Kajian mengenai penggunaan telefon pintar di seluruh dunia mendapati pada tahun 2014 penggunaan telefon pintar mencecah kira- kira 1.75 billion. Dalam kajian tersebut juga didapati $83 \%$ daripada penggunaan internet adalah melalui telefon bimbit. Manakala di Malaysia, mengikut data daripada Bank Dunia [15], kadar penembusan telefon bimbit pada tahun 2012 adalah sebanyak 141\%. Kadar ini menunjukkan peningkatan yang berlaku untuk tahun-tahun yang mendatang. Oleh itu, pepatah "segalanya dihujung jari" seakan-akan benar maknanya dalam era ledakan maklumat yang kian pesat. Hal ini kerana, pada masa kini kita dapat melihat pelbagai inovasi dari teknologi telah diperkenalkan yang membuktikan bahawa teknologi merupakan alat yang sangat membantu dalam kehidupan seharian manusia.

Salah satu cabaran dalam Wawasan 2020 adalah penggunaan teknologi yang memberi sumbangan kepada tamadun sain dan teknologi. Perkembangan pesat teknologi maklumat dan komunikasi memberi impak kepada pelbagai aspek kehidupan. Malah pendidikan juga turut tidak ketinggalan dalam menerima ilmu teknologi untuk dijadikan sesuatu yang baharu. Perkembangan dalam bidang teknologi juga telah mengubah cara manusia belajar. Di samping itu, proses pembelajaran pada masa kini telah melampaui ruang fizikal bilik darjah [16]. Selain itu, ia juga bersifat globalisasi dan sepanjang hayat. Teknologi merupakan jambatan antara pengalaman pelajar dan pengetahuan sedia ada dengan ilmu yang baru diajar dan dipelajari yang juga merupakan industri dalam teori 


\section{konstruktruktivisme.}

Era ini, gaya hidup pembelajaran yang diterima oleh pelajar berubah seratus peratus dengan adanya teknologi sebagai alat bantu mengajar. Hal ini dapat dilihat dengan lebih jelas dari segi mendapatkan maklumat atau nota pembelajaran. Melalui internet yang sudah melebar luas, pelajar tidak perlu lagi bergantung kepada guru dalam menerima maklumat tentang pembelajaran kerana mereka mampu mengakses sendiri maklumat tersebut dengan menggunakan komputer peribadi atau telefon pintar. Hal ini dikukuhkan lagi dengan pengakuan oleh beberapa orang pengkaji mengenai kelebihan dan potensi teknologi mudah alih dalam PdPc. Menurut kajian yang dijalankan oleh [16], beliau menyatakan bahawa pembelajaran yang menggunakan teknologi ini banyak kelebihan dan dapat meningkatkan pembelajaran tidak formal pelajar. Hal ini secara tidak langsung sesi pembelajaran sebenarnya telah berjalan semasa menggunakan teknologi mudah alih ini.

Selaras dengan ciri-ciri mudah alih yang diperkenalkan oleh Ozdamli dan Cavus [17], dimana ia bersifat campuran (Blended). Sistem persekolahan kini telah berubah daripada KSSR dan KSSM kepada Kemahiran Berfikir Aras Tinggi (KBAT). Oleh itu, pelbagai strategi dan kaedah pembelajaran diperlukan dalam menjana kemahiran berfikir dalam kalangan pelajar. Beberapa ahli akademik telah menjalankan kajian yang melibatkan pelbagai strategi pengajaran dalam menjana KBAT pelajar dan respon yang diteima adalah positif.

\subsection{E-Learning}

E-learning merupakan suatu penyebaran pengetahuan pendidikan melalui internet. Ini menjadikan Elearning subset latihan berasaskan teknologi. Selain itu, ia juga menggabungkan beberapa aktiviti pembelajaran yang dijalankan di internet, dimana pembelajaran mudah alih adalah satu bahagian.

Di samping itu, E-Learning membolehkan pembelajaran kendiri dilaksanakan dengan lebih lancar dan berkesan. Hal ini dikatakan demikian kerana, pelajar boleh memilih masa, kandungan serta hala tuju pembelajaran mereka. Selain itu, pelajar juga berpeluang belajar tajuk yang sukar berulang kali sehingga pemahaman dapat dicapai dengan berkesan. Menurut Najib [18], beliau mendapati keyakinan kendiri yang tinggi dalam penggunaan E-Learning secara tidak langsung dalam dapat melahirkan pelajar yang lebih celik dalam teknologi dan membentuk pelajar yang cemerlang secara holistik dari semua perkara pada masa yang sama.

\subsection{M-Learning}

M-Learning atau pembelajaran mudah alih merupakan suatu konsep baru dalam proses pembelajaran. Ia merupakan salah satu pendekatan pembelajaran kendiri dimana para pelajar mempelajari sesuatu pengetahuan mengikut kemampuan masing-masing. M- Learning tertumpu pada ciri-ciri teknologi mudah alih, namun telah memberikan konsep yang lebih canggih dengan menunjukkan penggunaan teknologi mudah alih seperti telefon pintar merupakan salah satu alat yang boleh digunakan untuk proses

PdPc yang kian hangat diperkatakan pada masa kini [16]. Hal ini dapat dilihat bahawa M-Learning memberi peluang untuk para pelajar dimana mereka boleh akses sumber-sumber pembelajaran secara digital walau dimana mereka berada. Perkara ini disokong juga oleh Ozdamli \& Cavus [17] yang menyatakan bahawa kemajuan dalam peranti mudah alih telah memudahkan penggunaan multimedia dalam aplikasi mudah alih yang membolehkan pelajar untuk mengakses kepada pelbagai sumber pembelajaran. Teknologi mudah alih terutamanya telefon pintar telah menjadi tumpuan dalam MLearning. Hal ini dikatakan demikian kerana, hampir satu setengah billion orang di alam ini membawa telefon pintar sepanjang masa dengan mereka. Peningkatan akses kepada telefon pintar dilihat mempunyai potensi untuk memberi sumbangan kepada pendidikan di setiap negara. M-Learning berkembang subur dalam paradigma konstruktivisme sosial kontemporari kerana kekayaan dari segi $\mathrm{P}$

Pembelajaran menggunakan teknologi mudah alih seperti M-Learning dapat menarik minat pelajar dalam memahami sesuatu pelajaran. Hal ini kerana melalui aplikasi mudah alih pelajar diberi kebebasan dalam menghantar tugasan, memuat turun nota, berbincang, menjawab kuiz serta melakukan aktiviti pembelajaran mengikut kehendak dan masa mereka. Menurut Triantafillou et al. [15], melalui kajian mereka dari segi ujian penilaian mendapati bahawa penilaian yang dilakukan melalui M-learning adalah lebih efektif dan efisien kerana lebih menjimatkan masa berbanding ujian yang menggunakan pen dan kertas. Penggunaan M-Learning akan memberi kesan yang positif kepada beberapa bidang seperti M-Learning membantu pelajar meningkatkan kemahiran literasi dan numerik untuk mengenalpasti keupayaan sebenar mereka, M-Learning boleh digunakan untuk menggalakkan kedua-dua pengalaman pembelajaran bebas dan pengalaman pembelajaran perkongsian (collaborative 
learning), M-Learning dapat membantu pelajar mengenalpasti perkara-perkara yang memerlukan bantuan dan sokongan, M-Learning dapat membantu dalam memperjuangkan penggunaan teknologi maklumat dan komunikasi serta dapat membantu mengurangkan jurang antara literasi telefon mudah alih dengan literasi teknologi maklumat, M-Learning membantu pelajar menolak beberapa formaliti daripada pengalaman pembelajaran, M-Learning membantu pelajar dalam mengekalkan fokus pembelajaran untuk jangka masa yang lebih panjang, M-Learning membantu meningkatkan selfesteem dan M-Learning membantu meningkatkan keyakinan diri.

\subsection{Perbezaan E-Learning dan M-Learning}

Jadual 1 mempamerkan perbezaan perbezaan E-Learning dan M-Learning.

Jadual 1. Perbezaan E-Learning dan M-Learning [19]

\begin{tabular}{|c|c|c|}
\hline Aspek & E-Learning & M-Learning \\
\hline Tempat & $\begin{array}{l}\text { - Kuliah di bilik darjah atau internet } \\
\text { makmal }\end{array}$ & $\begin{array}{l}\text { - Pembelajaran bila-bila masa, di } \\
\text { mana sahaja }\end{array}$ \\
\hline Pedagogi & - Lebih kepada teks dan grafik & $\begin{array}{l}\text { - Lebih berdasarkan suara, grafik } \\
\text { dan animasi }\end{array}$ \\
\hline $\begin{array}{l}\text { Komunikasi } \\
\text { Pengajar } \\
\text { Kepada Pelajar }\end{array}$ & $\begin{array}{l}\text { - Emel kepada emel. } \\
\text { - Komunikasi menjadi pasif }\end{array}$ & $\begin{array}{l}\text { - Mesej serta merta } \\
\text { - Komunikasi aktif }\end{array}$ \\
\hline $\begin{array}{l}\text { Komunikasi } \\
\text { Pelajar Kepada } \\
\text { Pengajar }\end{array}$ & $\begin{array}{l}\text { - } \text { Bersemuka. } \\
\text { - Lokasi tertentu yang mempunyai } \\
\text { internet } \\
\text { - Mengambil masa yang lama } \\
\text { untuk akses } \\
\text { - Komunikasi yang tidak baik untuk } \\
\text { berkumpulan }\end{array}$ & $\begin{array}{ll}\text { - } & \text { Fleksibel } 24 \text { jam } \\
\text { - Tiada sempadan georgrafi } \\
\text { - Masa yang singkat untuk akses } \\
\text { - Komunikasi yang baik untuk } \\
\text { kumpulan }\end{array}$ \\
\hline Tugasan & $\begin{array}{l}\text { - Dalam kelas } \\
\text { - Jumlah masa terhad }\end{array}$ & $\begin{array}{l}\text { - Di mana-mana } \\
\text { - } \text { Masa tidak terhad }\end{array}$ \\
\hline
\end{tabular}

\subsection{Kajian Ke Atas Produk Sedia Ada}

Kajian ke atas produk yang sedia ada mahupun lampau penting bagi mengenal pasti kelebihan dan kelemahan produk sedia ada yang terdapat dipasaran semasa. Perkara ini penting dalam mengenalpasti ciri-ciri tambahan yang boleh diberi penekanan untuk diinovasikan ke dalam aplikasi yang dibangunkan. Kebanyakan sistem sedia ada merupakan perisian hak milik yang memerlukan pengguna untuk membeli perisian tersebut. Ia lebih bersifat invidu kerana tidak membenarkan pengguna yang ramai mengakses perisian tersebut. Terdapat beberapa aplikasi telah dipilih untuk dijadikan sebagai rujukan dan perbandingan seperti Algorithms dan M-ISTech.

\subsubsection{Algorithms}

Algorithms: Explain and Animated adalah merupakan aplikasi yang dibangunkan oleh Moriteru Ishida yang berasal dari Jepun.

Aplikasi ini direka untuk pelajar bagi memudahkan mereka mempelajari Algoritma secara simulasi. Terdapat beberapa simulasi yang terkandung dalam aplikasi ini bagi memahami teknik-teknik yang diguna pakai dalam Algoritma. Contohnya seperti teknik penyusunan, pengelompokan, senarai carian graf dan sebaginya. Namun, tidak semua simulasi ini mampu diakses secara percuma.

Aplikasi Algorithms adalah sebuah aplikasi yang boleh dikatakan mengikut ciri-ciri dalam aplikasi. Antara kelebihan yang terdapat dalam aplikasi ini adalah mudah digunakan oleh pengguna, penggunaan elemen multimedia yang menarik dan skema warna yang bersesuaian digunakan untuk aplikasi ini. Namun masih terdapat kelemahan yang dikenal pasti dalam aplikasi ini. Contohnya seperti tidak mesra pengguna. Hal ini kerana, maklumat yang diberikan sukar difahami dan teks yang digunakan kurang jelas dan difahami. Seterusnya adalah grafik yang digunakan. Walaupun 
penyusunan dan reka bentuk ikon pada navigasi adalah konsisten, namun butang navigasi tidah mudah dikendalikan atau lebih mudah adalah sukar difahami oleh pengguna. Secara keseluruhannya, aplikasi yang dibangunkan ini masih berada pada tahap yang lemah kerana ciri kekuatan dan kelemahan yang ditunjukkan adalah pada tahap yang sama.

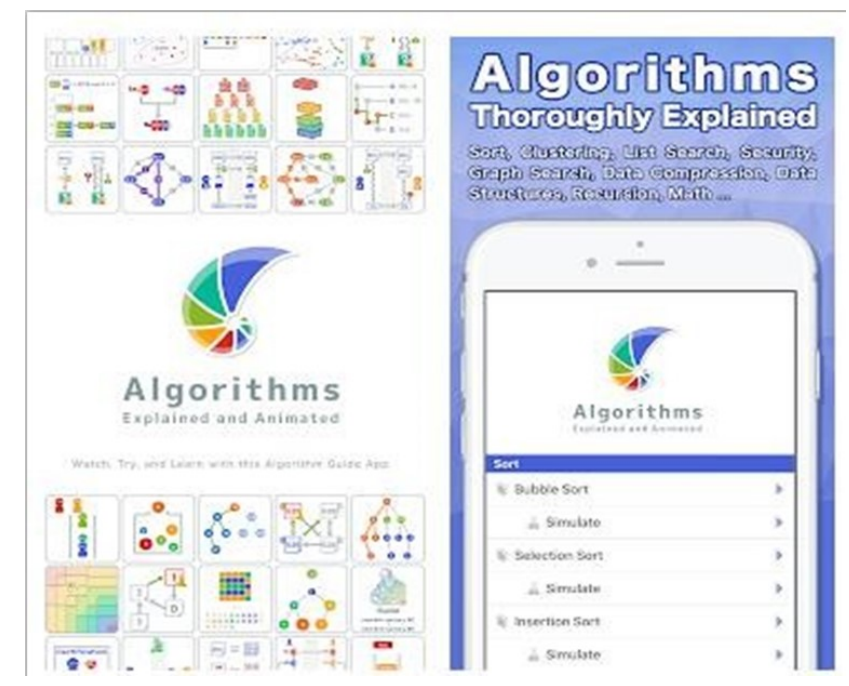

Rajah 1. Halaman Aplikasi Algorithms: Explain and Animated

\subsubsection{M-ISTech}

Pembangunan aplikasi mudah alih M-ISTech dibangunkan bagi kursus Sains Teknologi dan Kejuruteraan dalam Islam (DUA2012) yang diguna pakai oleh pelajar politeknik seluruh Malaysia. Aplikasi ini juga dibangunkan menerusi perisian Adobe Flash CS6 Platform Android. Kemudian, setelah dibangunkan, perisian ini akan menghasilkan sebuah aplikasi versi pengguna tunggal stand alone dalam bentuk format APK android application package. Format APK ini boleh dimuat naik (install) di mana-mana telefon yang mempunyai aplikasi Android sahaja. Isi kandungan yang terdapat dalam aplikasi ini adalah nota dan kuiz yang boleh digunakan oleh mahasiswa yang mengikuti kursus ini.
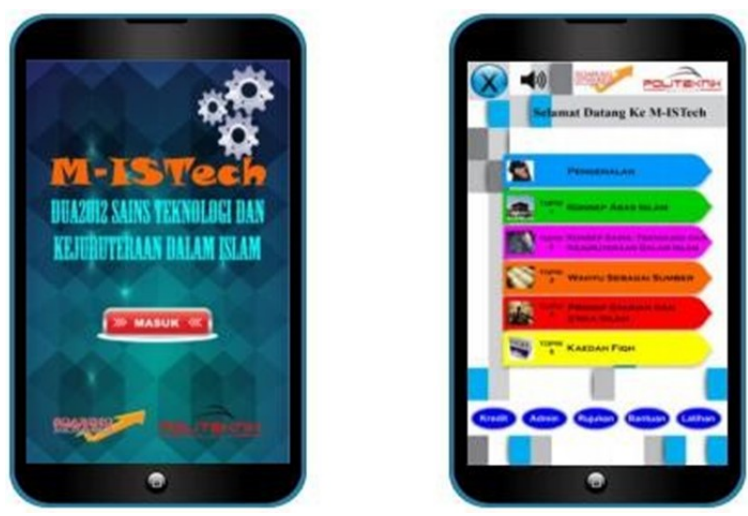

Rajah 2. Halaman Aplikasi M-ISTeach

M-ISTeach mempunyai banyak kelebihan seperti mesra pengguna dan mudah digunakan. Teks yang dimasukkan adalah jelas dan mudah difahami oleh pengguna dan pengisian yang menarik. Isi kandungan yang terdapat dalam aplikasi ini mengikut silibus pembelajaran dan perkara ini sudah pastinya memudahkan pelajar untuk membuat rujukan dan menjadikan aplikasi ini salah satu sebagai 
bahan rujukan yang terpenting. Namun begitu, terdapat juga beberapa kelemahan seperti skema warna yang digunakan kurang bersesuai. Hal ini kerana apabila dilihat, aplikasi tersebut kurang menarik perhatian dengan warna yang digunakan. Selain itu, penggunaan grafik yang kurang menarik ditampilkan dalam aplikasi ini dan kurangnya penggunaan elemen multimedia seperti video, audio dan animasi. Sungguhpun begitu, penyusunan dan reka bentuk ikon pada butang adalah konsisten dan butang navigasi tersebut mudah dikendalikan. Oleh itu, secara keseluruhannya, aplikasi ini masih lagi perlu diinovasikan agar menjadi aplikasi yang mempunyai elemen-elemen multimedia yang menarik.

\subsubsection{Kelebihan dan Kekuatan Produk Yang Sedia Ada Berbanding Produk Semasa} Jadual 2 mempamerkan kekuatan dan kelebihan produk sedia ada dan produk yang akan dibangunkan.

Jadual 2. Kekuatan dan Kelebihan Produk

\begin{tabular}{lccc}
\hline \multirow{2}{*}{ CIRI-CIRI } & Algorithms & M-ISTech & $\begin{array}{c}\text { Algoritma } \\
\text { Bersama Algo }\end{array}$ \\
\cline { 2 - 4 } & $\sqrt{ }$ & $\sqrt{ }$ & $\sqrt{ }$ \\
\hline Mudah digunakan & $\mathrm{X}$ & $\mathrm{X}$ & $\sqrt{ }$ \\
\hline Mesra Pengguna & $\sqrt{ }$ & $\mathrm{X}$ & $\sqrt{ }$ \\
\hline $\begin{array}{l}\text { Penggunaan elemen } \\
\text { multimedia yang menarik }\end{array}$ & $\sqrt{ }$ & $\sqrt{ }$ & $\sqrt{ }$ \\
\hline $\begin{array}{l}\text { Skema warna yang } \\
\text { digunakan bersesuaian }\end{array}$ & $\sqrt{ }$ & $\sqrt{ }$ & \\
\hline $\begin{array}{l}\text { Mengikut silibus } \\
\text { pembelajaran }\end{array}$ & $\sqrt{ }$ & $\mathrm{V}$ & $\sqrt{ }$ \\
\hline $\begin{array}{l}\text { Penyusunan dan rekabentuk ikon } \\
\text { pada navigasi } \\
\text { adalah konsisten. }\end{array}$ & $\mathrm{X}$ & $\sqrt{ }$ & $\sqrt{ }$ \\
\hline $\begin{array}{l}\text { Butang navigasi mudah } \\
\text { dikendalikan }\end{array}$ & $\mathrm{X}$ & $\mathrm{X}$ & $\sqrt{ }$ \\
\hline Grafik yang menarik & $\sqrt{ }$ & $\sqrt{ }$ & \\
\hline Pengisian yang menarik & & &
\end{tabular}

Berdasarkan Jadual 2, dilihat bahawa kekuatan dan kelebihan produk ini adalah lebih baik berbanding dengan produk sedia ada. Misalnya adalah mesra pengguna dan mudah digunakan dimana ia tidak memerlukan aplikasi sokongan yang lain untuk diakses. Seterusnya adalah penggunaan multimedia yang menarik diterapkan dalam aplikasi ini. Elemen seperti video, audia, grafik, teks dan animasi dimasukkan bagi menarik minat kumpulan sasaran iaitu pelajar tingkatan 1. Selain itu, skema warna yang digunakan sesuai dengan kebolehbacaan teks dengan jelas dan mudah difahami oleh pengguna. Aplikasi yang dibangunkan adalah bedasarkan sukatan mata pelajaran dalam ASK dan sudah pastinya pembangun mengikuti sukatan pelajaran agar objektif tercapai. Dari segi penyusunan dan reka bentuk ikon pada navigasi adalah konsisten dan butang navigasi juga mudah dikendalikan dimana dapat digunakan dengan baik dan lancar. Grafik yang dimasukkan adalah menarik dan sesuai. Akhir sekali adalah, pengisian yang terkandung dalam aplikasi Algoritma Bersama Algo adalah menarik kerana memiliki nota, tutorial, permainan dan video yang mampu membuat pengguna mencintai produk ini.

\section{Metodologi Kajian}

Sesi ini membincangkan mengenai metodologi kajian yang digunakan sepanjang proses pembangunan aplikasi "Algoritma Bersama Algo". Metodologi ini juga menerangkan kaedah dan teknik yang digunakan dalam kajian ini.

\subsection{Kaedah dan Rekabentuk Kajian}

Reka bentuk kajian adalah satu kerangka yang digunakan oleh sesebuah kajian bagi mengutip serta menganalisis data. Kajian ini merupakan kajian tinjauan yang bertujuan bagi mengumpul data 
daripada satu set populasi. Kajian tinjauan merupakan kaedah yang terbaik dalam mengumpul data yang asli daripada populasi yang besar melalui teknik persampelan. Pembangun telah memilih kuantitatif sebagai instrument bagi memungut data. Instrumen ini berfungsi sebagai alat pengukur dan menjadi alat perantara antara pembangun dengan responden. Oleh itu, kaedah yang dilaksanakan adalah dengan menggunakan borang soal selidik sebagai instrumen yang paling utama. Soal selidik dipilih sebagai alat kajian utama kerana maklumat yang diterima adalah secara terus daripada responden dalam masa yang singkat.

Kaedah termudah dan berkesan dalam memperoleh data piawai daripada saiz sampel kajian yang besar dan menyeluruh adalah soal selidik. Dalam kajian ini, pembangun menyediakan borang soal selidik kepada lima orang guru ICT dan 16 orang pelajar tingkatan 1 yang dipilih secara rawak. Borang soal selidik ini mempunyai beberapa bahagaian dan bahagian tersebut bagi melengkapkan sebahagian tugasan yang perlu dilaksanakan.

\subsection{Sampel Kajian}

Populasi kajian ini adalah pelajar-pelajar dari Tingkatan 1 yang mengambil mata pelajaran ASK. Pemilihan pelajar tingkatan 1 adalah bagi menyempurnakan tujuan utama aplikasi ini dibangunkan untuk pelajar tingkatan 1 yang mengikuti aliran ASK ini. Seterusnya, lima orang guru dari aliran ASK dijadikan sampel bagi melengkapkan objektif yang ketiga iaitu persepsi guru terhadap pengunaan aplikasi Algoritma Bersama Algo dalam pembelajaran Algoritma.

\subsection{Prosedur Kajian}

Pembangunan sesuatu produk pastinya memerlukan metodologi yang bersesuaian supaya pembangunan yang dilaksanakan berjalan dengan lancar dan baik. Setiap fasa mempunyai fungsi yang tersendiri dan dilalui bagi melengkapkan pembangunan aplikasi ini.

Menurut Reiser \& Dempsey [20], model reka bentuk merupakan satu proses yang sistematik dalam pembangunan sumber teknologi dan ia juga merangkumi analisis pembelajaran dan pencapaian, reka bentuk aplikasi, pembangunan, implementasi, dan penilaian. Dalam pembangunan aplikasi mudah alih pembangun melibatkan lima fasa utama iaitu yang diadaptasi daripada Model ADDIE. Model ADDIE ini dipilih untuk membangunkan aplikasi pembelajaran kerana reka bentuk model yang menekankan pengulangan dilakukan bagi setiap fasa. Setiap fasa ini saling berkait antara satu sama lain.

Model ADDIE merupakan model yang terawal dan menjadi asas kepada model yang lain. Model ADDIE merupakan model yang terawal dan menjadi asas kepada model-model reka bentuk yang lain [20] [21] [22] [23] [24] [25] [26]. Perkataan ADDIE merupakan satu singkatan daripada Analysis (analisis), Design (reka bentuk), Development (pembangunan), Implementation (perlaksanaan) dan Evaluation (penilaian). Rajah 3 menunjukkan model ADDIE yang dijadikan panduan dalam kajian ini.

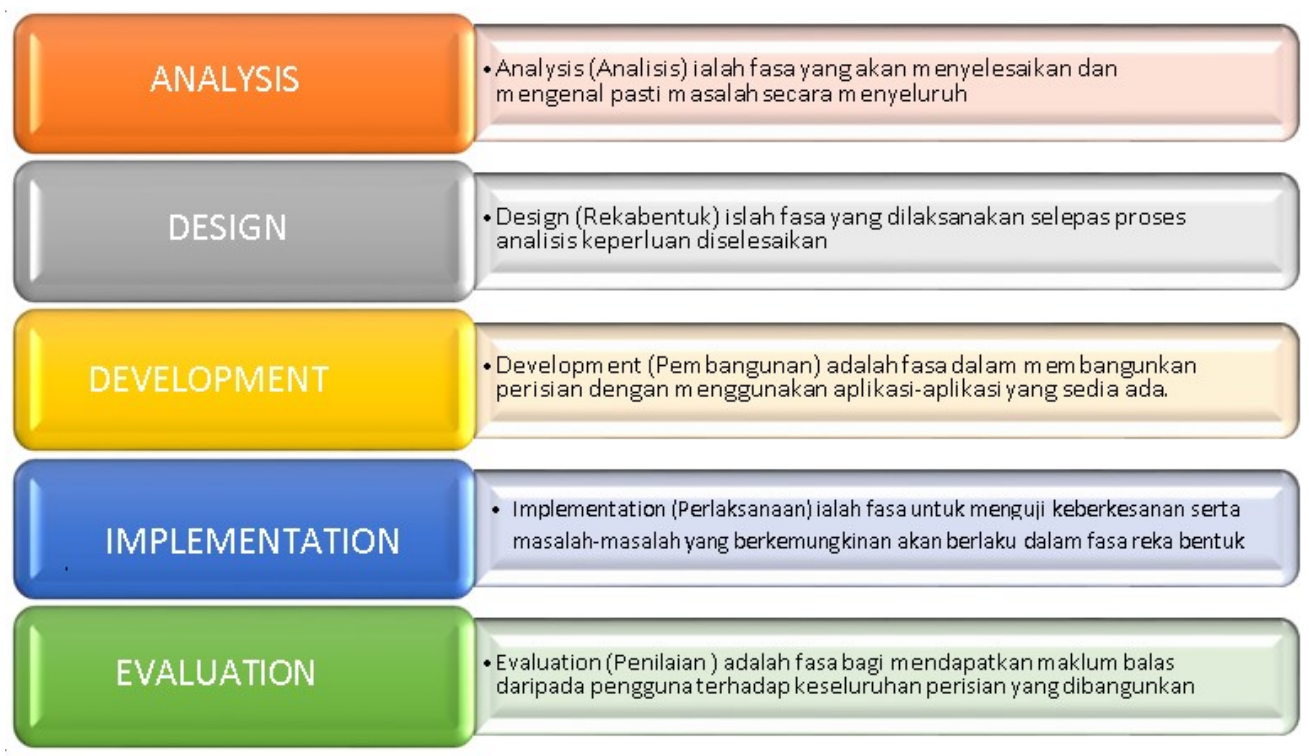

Rajah 3. Model ADDIE 


\subsubsection{Fasa Analisis}

Analisis (Analysis) merupakan fasa yang terawal atau lebih mudah difahami adalah yang pertama dalam model ADDIE. Pada peringkat ini juga beberapa analisis telah dilakukan seperti persekitaran pembelajaran, pengguna dan menentukan matlamat. Antara soalan yang boleh diajukan dalm proses analisis adalah seperti:

1. Siapakah pengguna dan apakah sifatnya?

2. Apakah jenis halangan dalam pembelajaran yang wujud?

3. Apakah pilihan bentuk penyampaian pembelajaran?

4. Berapa tempoh masa yang diperlukan bagi menyiapkan projek yang dibangunkan?

Melalui analisis permasalahan, secara tidak langsung ia berpontensi untuk menjadi tajuk projek dan juga menjadi faktor utama mengapa pembangun perlu membangunkan aplikasi mudah alih bagi topik Algoritma tingkatan 1 ini.

\subsubsection{Fasa Reka Bentuk}

Fasa reka bentuk (Design) adalah satu fasa yang amat penting dalam menentukan keseluruhan aplikasi yang dibangunkan. Dalam fasa ini, pembangun telah menerapkan elemen- elemen multimedia seperti audio, video, teks, garfik dan animasi. Penggunaan elemen multimedia menjadi satu kepentingan dalam sesebuah pembangunan aplikasi. Hal ini kerana ia secara tidak langsung dapat menarik minat dan tumpuan pelajar terhadap aplikasi ini. Bagi memudahkan proses perjalanan pembangunan aplikasi ini iaitu lebih teratur dan terancang, pembangun telah mengahasilkan papan cerita dan carta alir. Penghasilan papan cerita adalah salah satu perkara yang terpenting dalam fasa ini. Hal ini kerana dengan penghasilan papan cerita pembangun dapat menggambarkan aliran aplikasi yang dibangunkan.

\subsubsection{Fasa Pembangunan}

Fasa Pembangunan (Development) ini berfokuskan kepada pada pembinaan hasil daripada fasa reka bentuk yang dijalankan. Dalam fasa ini, pembangun telah mengumpulkan kesemua maklumat serta informasi yang diperoleh dari fasa yang terdahulu untuk dijalankan dalam fasa ini. Fasa yang terpenting dalam pembangunan ini adalah maklumat dari fasa reka bentuk. Setiap pembangunan diuji agar ia konsisten dan dapat beroperasi dengan lancar dan berkesan.

Dalam fasa ini, segala perancangan yang telah dibuat sebelum proses pembangunana dimulakan dalam fasa reka bentuk yang sebelumnya mula dibangunkan. Hal ini bermaksud langkah dari awal iaitu dari isi kandungan antara muka hingga ke langkah terakhir dilakukan dalam fasa ini. Ketika proses ini dibangunakan elemen yang dimasukkan oleh pembangun ialah audio, video, teks, animasi dan garfik dikumpul dan disiapkan. Pembangun menggunakan beberapa perisian seperti Adobe Flash (pembangunan aplikasi, animasi dan permainan), Audacity (audio) manakala untuk grafik dan teks pembangun menggunakan Adobe Photoshop dan Illustrator. Melalui perisian ini, pembangun dapat mempelbagaikan bahan yang terkandung dalam aplikasi yang dibangunkan.

Selain itu, pembangun juga telah menyediakan soal selidik dan diedarkan kepada guru dan pelajar. Pembangun akan menguji kesahihan aplikasi ini dengan meminta beberapa orang pensyarah untuk menilai tahap kesesuaian aplikasi yang dibangunkan.

\subsubsection{Fasa Pelaksanaan}

Fasa implementasi (Implementation) adalah fasa yang keempat dimana bahagian fasa pembangunan telah selesai dibangunkan. Pada peringkat ini, aplikasi yang dibangunkan telah diuji tahap keberkesanan dan kemudahgunaan perisian dalam keadaan yang sebenar. Pembangun menguji terlebih dahulu setiap butang yang disediakan adakah berhasil ataupun tidak. Aplikasi ini diuji bagi mengenal pasti kesilapan atau kelemahan yang terdapat semasa proses pembangunan berlaku. Jika masih berlaku kesalahan, pembangun juga memperbaiki kembali bahagian yang tidak berfungsi sehingga berjaya sebelum ia diserahkan sepenuhnya kepada pengguna sasaran untuk digunapakai. Seterusnya, pembangun boleh menyediakan dokumentasi serta borang soal selidik bagi mendapatkan maklum balas dari pengguna bagi menjadikan rujukan di fasa penilaian.

\subsubsection{Fasa Penilaian}

Fasa Penilaian (Evaluation) adalah yang terakhir yang perlu dilalui adalah fasa penilaian dimana produk yang telah disediakan dan diproses untuk mendapat maklum balas pengguna aplikasi terhadap keseluruhan produk. Ia meliputi keempat-empat tahap dalam model ADDIE iaitu analisis, reka bentuk, pembangunan dan pelaksanaan. Terdapat dua jenis penilaian utama iaitu dari segi formatif dan 
sumatif. Penilaian formatif merupakan penilaian berterusan semasa membentuk sesuatu tahap dan antara tahap. Manakala penilaian sumatif bermaksud penilaian keseluruhan produk yang telah dihasilkan. Proses penilaian ini dijalankan berdasarkan maklum balas daripada responden yang menggunakan aplikasi ini. Maklumat diterima dengan cara memberi borang soal selidik kepada pengguna. Kemudian, pembangun mula menganalisis maklumat yang diterima dan sebarang cadangan bagi penambahbaikan aplikasi.

\subsection{Carta Alir Reka Bentuk Produk}

Aplikasi Algoritma Bersama Algo mempunyai enam antara muka (interface). Antaranya ialah paparan utama, paparan nota, paparan tutorial, paran permainan, paparan video dan paparan manual pengguna. Paparan masuk mempunyai butang navigasi dimana jika butang tersebut disentuh, secara tidak langsung halaman tersebut akan berubah kepada paparan utama atau menu utama. Dalam paparan utama, pengguna boleh memilih butang navigasi yang dikehendaki. Misalnya, jika pengguna ingin ke paparan permainan, pengguna hanya perlu menyentuh butang navigasi untuk ke halaman tersebut.

Setiap antara muka yang disediakan mempunyai kepentingan yang tersendiri. Contohnya seperti papapran nota, pengguna perlu memilih tajuk yang diinginkan berdasarkan isi kandungan yang disediakan. Berbeza pula pada paparan tutorial dimana terdapat dua jenis kuiz atau latihan yang perlu dijawab oleh pengguna. Pada kuiz peringkat yang pertama, pengguna perlu menjawab lima soalan yang telah disediakan dan setelah selesai pelajar akan ke peringkat kedua dan seterusnya ketiga. Pada kuiz yang kedua pula, pengguna perlu menjawab soalan struktur yang diperuntukkan. Selain itu, paparan permainan pula mengandungi dua jenis permainan yang berbeza iaitu mencari simbol carta alir yang tersembunyi dan meneka silang kata berdasarkan soalan yang diberikan. Aplikasi ini juga turut menyediakan halaman video dimana terdapat tiga video yang berbeza tajuknya berdasarkan topik yang dipilih. Kandungan dalam video tersebut mengandungi nota dan juga cara-cara melaksanakan pseudokod dan carta alir berdasarkan permasalahan yang diberikan. Akhir sekali ialah halaman manual pengguna. Pada paparan ini, pengguna diberikan informasi berkaitan cara-cara penggunaan aplikasi Algoritma Bersama Algo.

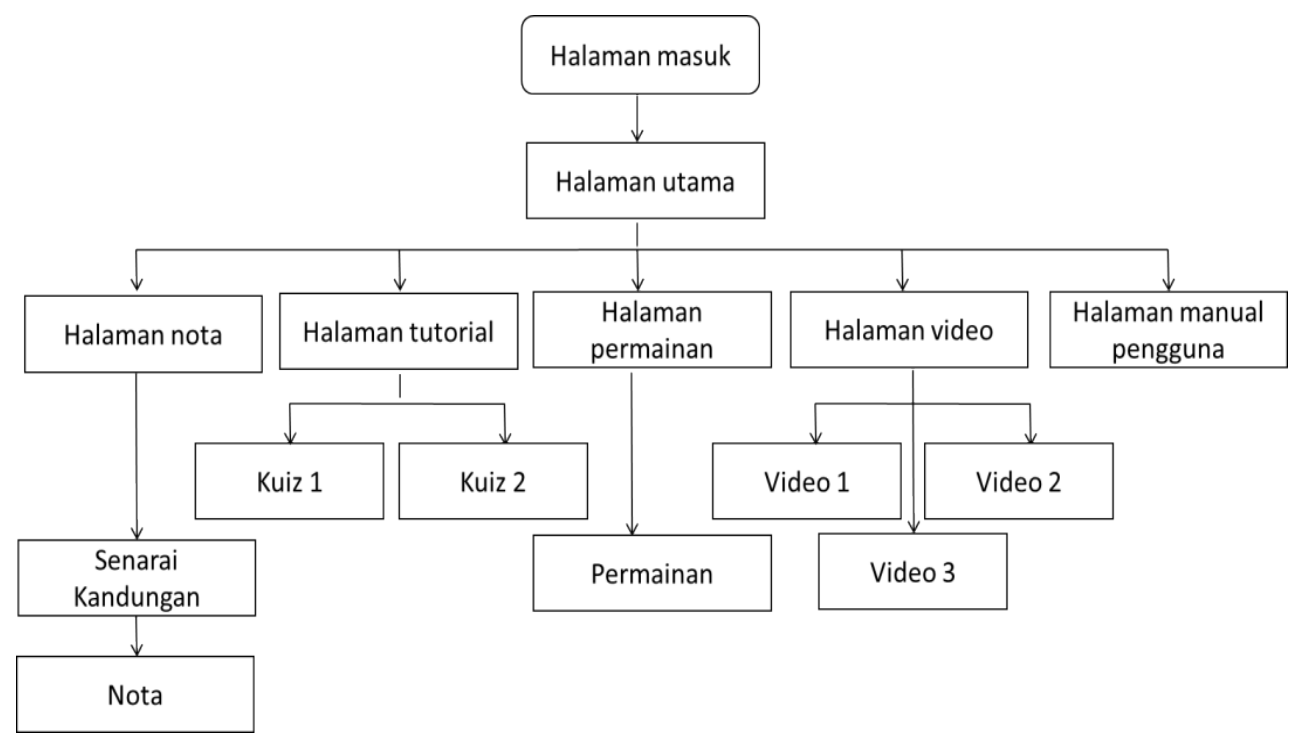

Rajah 4. Carta Alir Aplikasi "Algoritma bersama Algo"

\section{Dapatan Kajian dan Analisis}

\subsection{Reka Bentuk Antar Muka}

Rajah 5 menunjukkan antara muka halaman masuk yang mempunyai butang masuk pada logo Algo. Apabila pengguna klik pada butang tersebut mereka akan dibawa ke halaman utama. Kombinasi warna 
yang digunakan untuk antara muka adalah bersesuaian dan menarik perhatian pengguna serta menjadikan aplikasi ini lebih ceria.

\subsection{Maklum Balas daripada Responden: Guru}

Kajian ini melibatkan lima orang responden yang terdiri daripada beberapa orang guru bagi mata pelajaran ASK. Responden perempuan mengumpul undian tertinggi dalam menjawab soal selidik ini. Angka yang dikumpul adalah sebanyak $80 \%$ bersamaan dengan 4 orang guru. Seterusnya diikuti dengan bilangan lelaki dengan hanya seorang sahaja guru lelaki yang terlibat.

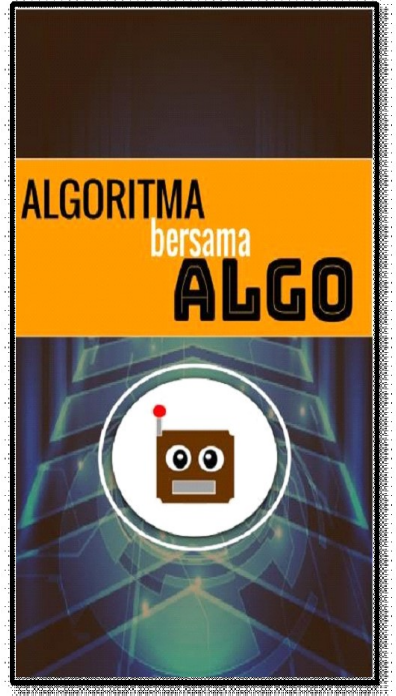

(a)

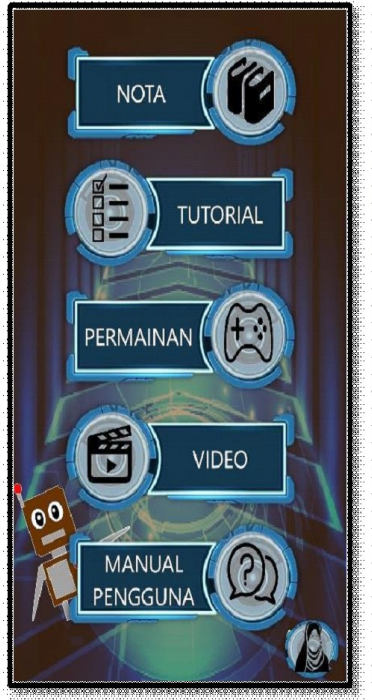

(b)

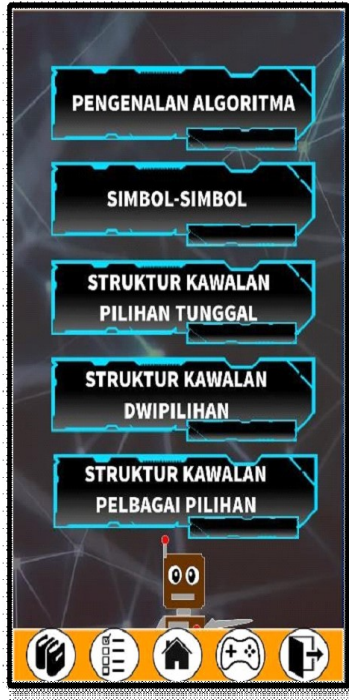

(c)

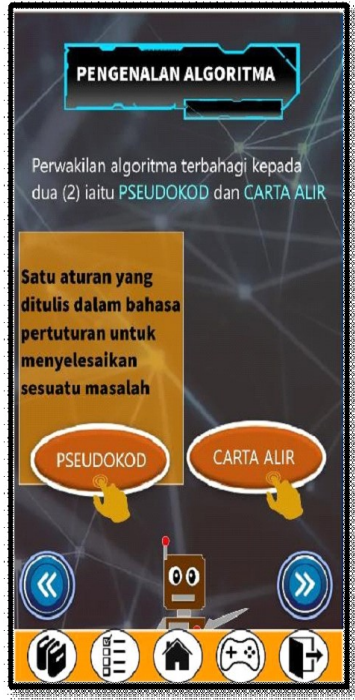

(d)
Rajah 5. Antara Muka: (a) Halaman Masuk
(b) Halaman Utama
(c) Halaman Nota
(d) Senarai Kandungan

\subsubsection{Analisis Penilaian Interaktiviti dan Reka Bentuk Aplikasi Algoritma Bersama Algo}

Pada bahagian ini, responden memberi maklum balas setelah menggunakan aplikasi Algoritma Bersama Algo. Penilaian pada bahagian ini adalah berdasarkan elemen-elemen dalam interaktiviti dan reka bentuk aplikasi seperti mudah digunakan, kebolehbacaan teks yang jelas dan mudah difahami, skema warna yang bersesuaian dan penyusunan ikon, video yang menarik dan audio yang jelas dalam video yang dihasilkan.

Jadual 3. Taburan Respon: Interaktiviti dan Reka Bentuk Aplikasi Algoritma Bersama Algo

\begin{tabular}{|c|c|c|c|c|c|c|}
\hline \multirow{2}{*}{ BIL } & \multirow{2}{*}{ PERKARA } & \multicolumn{5}{|c|}{ SKALA } \\
\hline & & 1 & 2 & 3 & 4 & 5 \\
\hline 1 & Aplikasi Algoritma ini mudah digunakan. & & & & $\begin{array}{c}2 \\
(40 \%)\end{array}$ & $\begin{array}{c}3 \\
60 \%)\end{array}$ \\
\hline 2 & $\begin{array}{l}\text { Kebolehbacaan teks yang jelas dan mudah } \\
\text { difahami. }\end{array}$ & & & $\begin{array}{c}1 \\
(20 \%)\end{array}$ & $\begin{array}{c}1 \\
(20 \%)\end{array}$ & $\begin{array}{c}3 \\
(60 \%)\end{array}$ \\
\hline 3 & Skema warna yang sesuai dan menarik. & & & & $\begin{array}{c}3 \\
(60 \%)\end{array}$ & $\begin{array}{c}2 \\
(40 \%)\end{array}$ \\
\hline 4 & $\begin{array}{l}\text { Penyusunan ikon pada butang navigasi pada } \\
\text { Aplikasi Algoritma adalah konsisten. }\end{array}$ & & & & $\begin{array}{c}3 \\
(60 \%)\end{array}$ & $\begin{array}{c}2 \\
(40 \%)\end{array}$ \\
\hline 5 & $\begin{array}{l}\text { Video yang menarik Audio di dalam video } \\
\text { jelas. }\end{array}$ & & & & $\begin{array}{c}4 \\
(80 \%)\end{array}$ & $\begin{array}{c}1 \\
(20 \%)\end{array}$ \\
\hline
\end{tabular}

Sangat Tidak Setuju (1), Tidak Setuju (2), Kurang Setuju (3), Setuju (4), dan Sangat Setuju (5). 


\subsubsection{Analisis Penilaian Reka Bentuk Pembelajaran}

Pada bahagian ini, responden memberi maklum balas setelah menggunakan aplikasi Algoritma Bersama Algo. Penilaian pada bahagian ini berdasarkan elemen-elemen reka bentuk pembelajaran.

Jadual 4. Taburan Respon: Reka Bentuk Pembelajaran

\begin{tabular}{|c|c|c|c|c|c|c|}
\hline \multirow{2}{*}{ BIL } & \multirow{2}{*}{ PERKARA } & \multicolumn{5}{|c|}{ SKALA } \\
\hline & & 1 & 2 & 3 & 4 & 5 \\
\hline 1 & Informasi yang diberikan ringkas dan padat. & & & & $\begin{array}{c}3 \\
(60 \%)\end{array}$ & $\begin{array}{c}2 \\
(40 \%)\end{array}$ \\
\hline 2 & $\begin{array}{l}\text { Informasi yang diberikan dapat disampaikan } \\
\text { dengan teratur dan jelas. }\end{array}$ & & & & $\begin{array}{c}2 \\
(40 \%)\end{array}$ & $\begin{array}{c}3 \\
(60 \%)\end{array}$ \\
\hline 3 & Isi pembelajaran mengikut DSKP & & & & $\begin{array}{c}1 \\
(20 \%)\end{array}$ & $\begin{array}{c}4 \\
(80 \%)\end{array}$ \\
\hline 4 & Contoh bagi setiap isi bersesuaian & & & & $\begin{array}{c}2 \\
(40 \%)\end{array}$ & $\begin{array}{c}3 \\
(60 \%) \\
(60 \%\end{array}$ \\
\hline 5 & $\begin{array}{l}\text { Tutorial membantu pelajar untuk berfikir } \\
\text { lebih kritis }\end{array}$ & & & & $\begin{array}{c}1 \\
(20 \%)\end{array}$ & $\begin{array}{c}4 \\
(80 \%)\end{array}$ \\
\hline 6 & $\begin{array}{l}\text { Permainan yang dihasilkan bersesuaian } \\
\text { dengan topik }\end{array}$ & & & & $\begin{array}{c}3 \\
(60 \%)\end{array}$ & $\begin{array}{c}2 \\
(40 \%)\end{array}$ \\
\hline
\end{tabular}

Sangat Tidak Setuju (1), Tidak Setuju (2), Kurang Setuju (3), Setuju (4), dan Sangat Setuju (5).

\subsection{Maklum Balas daripada Responden: Pelajar}

Kajian ini melibatkan 16 orang responden yang terdiri daripada pelajar. Responden yang mengutip undian tertinggi dalam menjawab borang soal selidik ini adalah perempuan. Angka yang dikutip adalah sebanyak $62.5 \%$ bersamaan dengan sepuluh orang pelajar. Seterusnya diikuti dengan bilangan lelaki seramai enam orang dan menjadikan angka peratusan adalah $37.5 \%$. Jika dibandingkan bilangan kedua-dua responden, perempuan lebih mengunggulinya kerana bilangan pelajar yang mengambil aliran Asas Sains Komputer di SMJK Dingdings kebanyakannya terdiri daripada responden perempuan.

\subsubsection{Analisis Penilaian Kebolehgunaan Aplikasi Algoritma Bersama Algo}

Pada bahagian ini, responden memberi maklum balas berdasarkan penggunaan aplikasi Algoritma Bersama Algo. Penilaian pada bahagian ini adalah berdasarkan beberapa elemen dalam kebolehgunaan aplikasi seperti mesra pengguna, mudah digunakan, kebolehbacaan teks yang jelas dan mudah difahami, skema warna yang bersesuaian dan penyusunan ikon.

Jadual 5. Taburan Respon: Kebolehgunaan Aplikasi Algoritma Bersama Algo

\begin{tabular}{clcccc}
\hline \multirow{2}{*}{ BIL } & \multirow{2}{*}{ PERKARA } & \multicolumn{3}{c}{ SKALA } \\
\cline { 3 - 5 } & Aplikasi Algoritma ini mesra pengguna & & & $\mathbf{3}$ & $\mathbf{4}$ \\
\hline \multirow{2}{*}{1} & & & 5 & 11 \\
& & & $(31.25 \%)$ & $(68.75 \%)$ \\
\hline 2 & Aplikasi Algoritma ini mudah digunakan & 4 & 12 \\
& & & $(25 \%)$ & $(75 \%)$ \\
\hline 3 & Kebolehbacaan teks yang jelas dan mudah & & 8 & 8 \\
& & $(50 \%)$ & $(50 \%)$ \\
\hline 4 & difahami. & Skema warna yang sesuai dan menarik & & 11 & 5 \\
& & & $(68.75 \%)$ & $(31.25 \%)$ \\
\hline 5 & Penyusunan ikon pada butang navigasi pada & & 8 & 8 \\
& Aplikasi Algoritma adalah konsisten. & $(50 \%)$ & $(50 \%)$ \\
\hline
\end{tabular}

Sangat Tidak Setuju (1), Tidak Setuju (2), Kurang Setuju (3), Setuju (4), dan Sangat Setuju (5). 


\subsubsection{Analisis Penilaian Reka Bentuk Isi Kandungan}

Pada bahagian ini, responden memberi maklum balas mengenai reka bentuk dan isi kandungan berdasarkan penggunaan aplikasi Algoritma Bersama Algo. Penilaian pada bahagian ini adalah bedasarkan beberepa elemen dalam reka bentuk seperti yang dinyatakan dalam perkara Jadual 6 .

Jadual 6. Taburan Respon: Reka Bentuk Isi Kandungan

\begin{tabular}{|c|c|c|c|c|c|c|}
\hline \multirow{2}{*}{ BIL } & \multirow{2}{*}{ PERKARA } & \multicolumn{5}{|c|}{ SKALA } \\
\hline & & 1 & 2 & 3 & 4 & 5 \\
\hline 1 & $\begin{array}{l}\text { Informasi pada butang navigasi mudah } \\
\text { difahami }\end{array}$ & & & & $\begin{array}{c}7 \\
(43.75 \%)\end{array}$ & $\begin{array}{c}9 \\
(56.25 \%)\end{array}$ \\
\hline 2 & Grafik yang digunakan menarik & & & & $\begin{array}{c}7 \\
(43.75 \%)\end{array}$ & $\begin{array}{c}9 \\
(56.25 \%)\end{array}$ \\
\hline 3 & $\begin{array}{l}\text { Latar belakang perisian tidak membebankan } \\
\text { penglihatan }\end{array}$ & & & & $\begin{array}{c}8 \\
(50 \%) \\
\end{array}$ & $\begin{array}{c}7 \\
(56.25) \\
\end{array}$ \\
\hline 4 & $\begin{array}{l}\text { Saiz tulisan yang digunakan dapat dilihat } \\
\text { dengan jelas }\end{array}$ & & & & $\begin{array}{c}5 \\
(31.25 \%) \\
\end{array}$ & $\begin{array}{c}11 \\
(68.75 \%) \\
\end{array}$ \\
\hline 5 & $\begin{array}{l}\text { Butang navigasi yang digunakan mudah } \\
\text { difahami. }\end{array}$ & & & & $\begin{array}{c}7 \\
(43.75 \%)\end{array}$ & $\begin{array}{c}9 \\
(56.25 \%) \\
\end{array}$ \\
\hline
\end{tabular}

Sangat Tidak Setuju (1), Tidak Setuju (2), Kurang Setuju (3), Setuju (4), dan Sangat Setuju (5).

\subsubsection{Analisis Penilaian Reka Bentuk Pembelajaran}

Pada bahagian ini, pembangun akan menganalisis maklum balas yang diberikan oleh responden mengenai reka bentuk pembelajaran.

Jadual 7. Taburan Respon: Reka Bentuk Pembelajaran

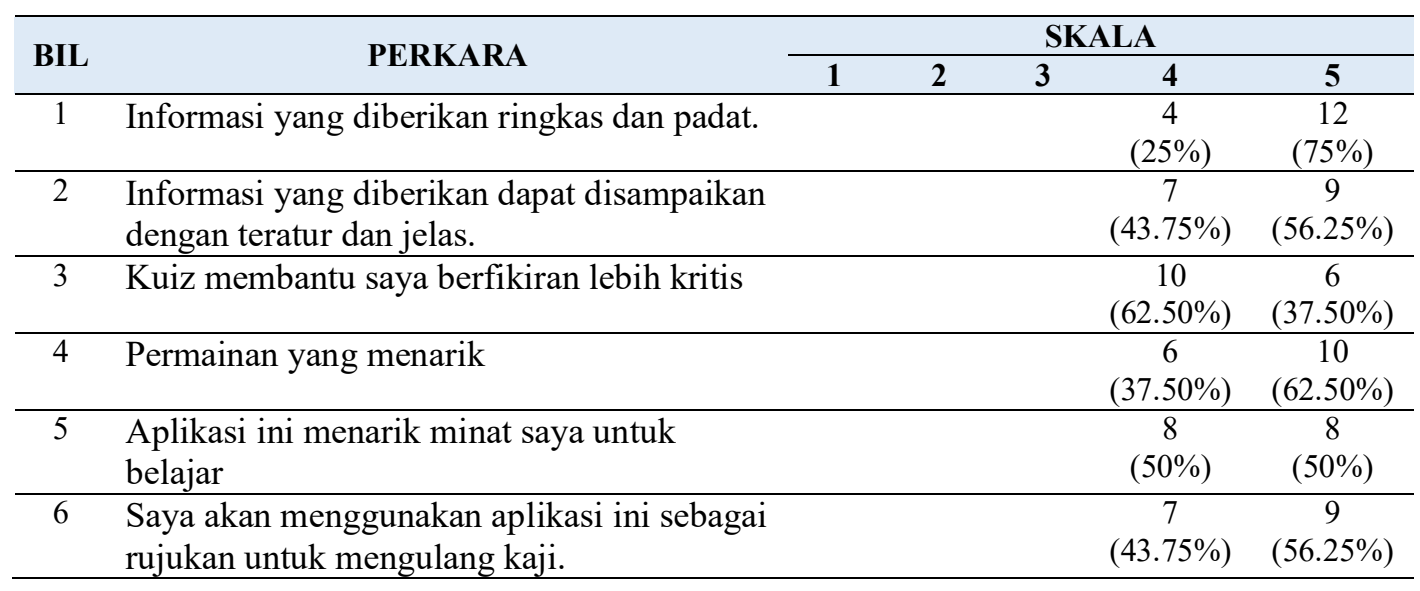

Sangat Tidak Setuju (1), Tidak Setuju (2), Kurang Setuju (3), Setuju (4), dan Sangat Setuju (5).

Bedasarkan kajian yang dilaksanakan, rata-rata responden berpuas hati dengan elemen multimedia yang diterapkan iaitu dari aspek animasi, video dan audio. Responden yang terdiri daripada guru sangat bersetuju mengenai permainan yang dibangunkan selaras dengn topik yang dipelajari dalam aplikasi ini. Berbeza pula dengan respoden yang terdiri daripada pelajar sangat bersetuju bahawa permainan yang dihasilkan sesuai dan menarik minat untuk terus belajar topik ini. 'Algo' merupakan watak utama dalam aplikasi ini, dan kemunculan Algo pada tiap skrin seolah-olah pengguna sedang belajar bersamanya dan menjadikan aplikasi ini tidak membosankan. Dari segi kebolehbacaan teks mendapat skor yang agak rendah dari beberapa orang guru. Hal ini kerana bagi sesetengah guru yang berusia berpendapat bahawa penggunaan warna atau saiz tulisan perlulah bersesuaian iaitu dapat dibaca dengan jelas. 
Bedasarkan soal selidik yang diberikan, para pelajar sangat berminat dengan aplikasi yang dibangunkan. Hal ini kerana, dengan penerapan beberapa elemen multimedia menjadikan pembelajaran bagi subjek ini menarik dan tidak membosankan untuk dipelajari. Maklum balas yang diberikan oleh guru juga posititif setelah aplikasi ini diuji oleh responden. Aplikasi yang dihasilkan mengikut peredaran semasa dalam penggunaan teknologi manakala dari segi reka bentuk dan isi pembelajaran pembangun menerapkan elemen yang menarik dan contoh yang sesuai bedasarkan kumupulan sasaran yang ditetapkan. Selain itu, beberapa cadangan yang positif yang diberikan membantu meningkatkan motivasi pembangun untuk menghasilkan produk yang berkualiti.

\section{Rumusan}

Permasalahan yang paling utama yang dihadapai oleh para pelajar mahupun guru adalah dalam mencari bahan rujukan untuk pembelajaran topik ini. Rentetan daripada permasalahan ini, pembangun telah membangun aplikasi yang menarik dimana dengan kemajuan teknologi pada masa kini, kesukaran mencari bahan rujukan tidak lagi menjadi punca utama kepada pengguna dalam menimba ilmu. Aplikasi Algoritma Bersama Algo dapat membantu pelajar dalam mencari rujukan pada bila-bila masa dan dimana jua pengguna berada. Berikut merupakan beberapa cadangan untuk penambahbaikan pada masa akan datang:

- Menambah isi kandungan aplikasi mudah alih

Secara kasarnya, isi kandungan dan maklumat yang terdapat di dalam aplikasi ini sudah memadai jika dilihat kepada kumpulan sasaran iaitu pelajar Tingkatan 1 yang secara umumnya sedia maklum bahawa pengguna teks yang banyak akan mengurangkan minat pelajar untuk belajar. Namun begitu, contoh yang diberikan masih belum cukup kerana kepelbagaian contoh yang menarik melalui teks juga merupakan salah satu daya tarikan yang dapat membantu pelajar lebih mudah faham mengenai topik yang dibangunkan dalam aplikasi ini.

- Penggunaan video dalam aplikasi

Penggunaan video adalah salah satu elemen multimedia yang dapat menarik minat pelajar. Sungguhpun begitu, video yang dihasilkan telah dihubungkan dengan yotube dimana pelajar perlu mempunyai data jika ingin meneruskan pembelajaran. Hal ini secara tidak langsung menjadikan pembelajaran pelajar terhenti sekiranya pengguna tidak mempunyai data untuk melihat video. Oleh itu, penambahbaikan pada masa akan datang adalah pembangun perlu membangunkan video bedasarkan perisian yang digunakan.

- Informasi perlu lebih jelas

Pembangun perlu meletakkan informasi dalam bahagian nota dengan lebih terperinci agar pengguna lebih mudah faham.

\section{Rujukan}

[1] A. R. Ahmad, "Kepentingan Kemajuan Teknologi Maklumat dan Komunikasi," 2011. [Online]. Available: http://www.flashkitech.com/?p=501 [Accessed: April. 10, 2012].

[2] A. S. Shuib, "Reka bentuk kurikulum M-Pembelajaran Sekolah Menengah: Teknik Delphi," Proceedings of Regional Conference on Knowledge Integration in Information and Communication Technology2010, pp. 652-665, 2010.

[3] I. Sukendar, B. Arifin, and F. S. Addin, "Analysis and Design of Coil Rolling Machines on Robot Solenoids using Macroergonomic MEAD and REBA Based on Arduino Microcontroller", International Journal of Education, Science, Technology, and Engineering, vol. 3, no. 2, pp. 35-47, Dec. 2020. https://doi.org/10.36079/lamintang.ijeste-0302.107

[4] C. Gabare, S. Gabarre, R. Din, P. M. Shah and A. A. Karim, "iPads in the foreign language classroom: A learner' s perspective," The Southeast Asian Journal of English Language Studies, vol. 20, no. 1, pp. 115-128, 2014.

[5] Norazrena and K. Anuar, Pengaplikasian Perisian Matematik bagi Tajuk Pecahan Terhadap Pelajar Pendidikan Khas. in Bahan Pengajaran dan Pembelajaran Berasaskan Komputer, pp. 201-218. Kuala Lumpur, 2007.

[6] A. B. Ibrahim, S. A. Ariffin, A. Abas, and M. F. Misbah, "Usability of Electrical E-Wiring Module Using Mobile Apps", International Journal of Education, Science, Technology, and Engineering, vol. 3, no. 2, pp. 60-66, Dec. 2020. https://doi.org/10.36079/lamintang.ijeste0302.141

[7] M. Sharples, P. McAndrew, M. Weller, R. Ferguson, E. T. Fit/Gerald and M. Gaved, Innovating 
Pedagogy 2013: Open University Innovation Report 2. Milton Keynes: The Open University, 2013.

[8] Sharifah Nor Puteh, and Kamarul Azman Abd Salam, "Tahap kesediaan penggunaan ICT dalam pengajaran dan kesannya terhadap hasil kerja dan tingkah laku pelajar prasekolah," Jurnal Pendidikan Malaysia, vol. 36, no. 1, pp. 25-34, 2011.

[9] A. Esa and S. Padil, "Kemahiran insaniah Dalam Program Senibina di Politeknik: Satu Sorotan Literatur," in Malay Journal, vol 4, no. 3, 2014.

[10] L. T. Tien and K. Osman, P"enggunaan modul multimedia interaktif dengan agen pedagogi dalam pelajaran elektronikimia: Kesan terhadap pemahaman konsep dalam elektronikimia," [Online]. Available: http://10.16.0.23/eget/docs/2013/39600_1365130614.pdf [Accessed: April 23, 2019].

[11] Z. A. Mutalib, "Pemikiran komputasional, sains komputer di sekolah tahun depan," Berita Harian, 2016. [Online]. Available: http://www.bharian.com.my/node/182091 [Accessed: May. 17, 2019].

[12] A. Hanis Ariffin and L. F. Md Ibharim, "Aplikasi Kahoot Sebagai Alat Pengujian Terhadap Pencapaian Murid dalam Mata Pelajaran Sejarah", International Journal of Education, Science, Technology, and Engineering, vol. 2, no. 2, pp. 90-96, Dec. 2019. https://doi.org/10.36079/lamintang.ijeste-0202.44

[13] M. F. Mohd Baharan, N. Mohsin, Mohd Nor Mamat, and Z. Temyati, "Penggunaan Sistem Persekitaran Pembelajaran Maya Frog di Sekolah-Sekolah Malaysia: Pengalaman dan Prospek Masa Depan ", International Journal of Education, Science, Technology, and Engineering, vol. 2, no. 2, pp. 84-89, Dec. 2019. https://doi.org/10.36079/lamintang.ijeste-0202.43

[14] F. Martin, and J. Ertzberger, "Here and now mobile learning:An experiment study on the use of mobile technology," Computers\& Education, vol. 68, pp. 76-85, 2013.

[15] E. Triantafillou, E. Georgiadou, A. A. Economides, The design and evaluation of a computeriaed adaptive test on mobile devices. Science Direct, pp. 1319-1330. Elservier, 2006.

[16] A.G. Kukulska-Hulme, and J. Traxler, Mobile Learning. A Handbook for Educator and Trainers. New York: Routedge Falmer, 2005.

[17] F. Ozdamli, and N. Cavus, "Basic Elements and Characteristics of Mobile Leraning," Procedia Social and Behavioral Svience, vol. 28, pp. 937-942, 2011.

[18] N. H. M. Najib, "E-Pembelajaran dalam Kalangan Pelajar di Institusi Pengajian Tinggi," in Proceeding of the 3rd International Conference onManagement \& Muamalah, 2016.

[19] Atikah, M. Jasmy and N. Atika, Pengadaptasian E-Learning Kepada M-learning Dalam Teknologi Pendidikan. Selangor: Universiti Kebangsaan Malaysia, 2017.

[20] R. A Reiser, and J. V. Dempsey, Trends and Issues in Instructional Desing and Technology (2nd Edition). Upper Saddle River, New Jersey: Merill PrenticeHall, 2007.

[21] C. Anwar and J. Riyanto, "Perancangan Sistem Informasi Human Resources Development Pada PT. Semacom Integrated", International Journal of Education, Science, Technology, and Engineering, vol. 2, no. 1, pp. 19-38, Jun. 2019. https://doi.org/10.36079/lamintang.ijeste0201.16

[22] Andreansyah, A. Rachman, and Rahmi, "Implementation of Incremental Models on Development of Web-Based Loan Cooperative Applications", International Journal of Education, Science, Technology, and Engineering, vol. 3, no. 1, pp. 26-34, Jun. 2020. https://doi.org/10.36079/lamintang.ijeste-0301.105

[23] L. Swastina and A. S. Riadi, "Implementation of Feeder System to Support Monitoring the Potential Malnutrition", International Journal of Education, Science, Technology, and Engineering, vol. 3, no. 2, pp. 48-59, Dec. 2020. https://doi.org/10.36079/lamintang.ijeste0302.114

[24] N. H. Hasbullah and N. A. Z. Mohd Noor, "Sistem Temujanji Interaktif Berasaskan WEB", Journal of Engineering, Technology, and Applied Science, vol. 2, no. 3, pp. 110-117, Dec. 2020. https://doi.org/10.36079/lamintang.jetas-0203.144

[25] M. Olva, R. Dwiputri Permatasari, S. Majid, P. Syair, and A. Suganda, "Pemanfaatan Dasbor pada Pemantauan Data Transaksi Penjualan", Journal of Engineering, Technology, and Applied Science, vol. 3, no. 1, pp. 1-15, Apr. 2021. https://doi.org/10.36079/lamintang.jetas-0301.188

[26] S. Apandi, O. Veza, S. Majid, and P. Pratiwi, "Penentuan Bonus Karyawan dengan Menggunakan Metode Analytic Network Process di PT. Global Harvest Precision Engineering", Journal of Engineering, Technology, and Applied Science, vol. 2, no. 1, pp. 51-58, Apr. 2020. https://doi.org/10.36079/lamintang.jetas-0201.94 